\title{
PENGARUH KEPERCAYAAN DAN KOMITMEN TERHADAP LOYALITAS KONSUMEN PENGGUNA JASA BENGKEL AUTO 2000 TANJUNG API-API PALEMBANG
}

\author{
Zubaidah Warni \\ Fakultas Ekonomi Universitas Palembang \\ Email: zubaidahunpal@gmail.com
}

\begin{abstract}
ABSTRAK
Tujuan penelitian ini adalah untuk mengetahui pengaruh kepercayaan dan komitmen terhadap loyalitas konsumen pengguna jasa bengkel Auto2000 Tanjung Api-api Palembang.Penelitian ini merupakan penelitian kuantitatif. Teknik pengumpulan data yang digunakan adalah kuesioner yang dibagikan kepada 78 responden yang dipilih menggunakan teknik purposive sampling. Metode analisis data yang digunakan adalah analisis regresi linier berganda.Hasil uji regresi berganda kepercayaan berpengaruh sebesar 0,493, komitmen sebesar 0,551, Berdasarkan uji koofiesien derterminasi $(R)^{2}$ loyalitas konsuemen kepercayaan dan komitmen berpengaruh sebesar 0,336 atau 33,6\% dan sisanya 66,4 dipengaruhi oleh variabel lain yang tidak dibahas dalam penelitian ini.
\end{abstract}

\section{Kata Kunci : Kepercayaan, Komitmen, dan Loyalitas}

\section{Pendahuluan}

\subsection{Latar Belakang}

Konsep pemasaran modern mengalami perkembangan dengan menempatkan konsumen sebagai perhatian utama. Produsen berlomba-lomba untuk sebisa mungkin dapat bersaing dengan kompetitor. Hal ini dapat dilihat dari semakin banyaknya perusahaan yang menghasilkan produk dengan jenis dan kegunaan yang sama akan tetapi berbeda harga dan pelayanan. Konsumen pun bersikap lebih selektif dan kritis dalam memilih produk yang akan dibeli. Konsumen tidak lagi membeli produk sekedar berdasarkan pertimbangan wujud fisik saja, namun juga termasuk segala aspek pelayanan yang melekat pada produk, mulai dari tahap pembelian sampai pada tahap pasca pembelian. Salah satu Perusahaan Transportasi juga merasakan ketatnya persaingan saat ini, karena seperti kita ketahui keinginan akan Kebutuhan transportasi dari waktu ke waktu terus mengalami peningkatan akibat semakin banyaknya kegiatan-kegiatan yang membutuhkan jasa transportasi. Kehidupan masyarakat pun akhirnya tidak bisa dipisahkan dari transportasi, sehingga banyaknya perushaan yang memberikan pelayanan dan kualitasnya dalam bidang trasnportasi terutama dibidang pelayanan jasa perbengkelan. Persaingan yang semakin ketat tersebut ditandai dengan makin banyaknya bengkel-bengkel bermunculan baik di kota besar maupun di kota kecil, dalam hal ini terutama di Kota Palembang. Pelanggan merupakan aset terbesar bagi perusahaan, karena tanpa adanya pelanggan perusahaan tidak akan ada.

Atas dasar itulah banyak pengusaha yang bergerak dibidang produk maupun jasa saling bersaing untuk mendapatkan pelanggan, karena pada dasarnya tujuan dari suatu bisnis adalah berusaha untuk mendapatkan pelanggan sebanyakbanyaknya serta mempertahankan loyalitas dari pelanggan tersebut. Loyalitas dapat terbentuk karena adanya kommitmen dan kepercayaan dari para konsumennya. $P T$ Astra International, Tbk - Toyota Sales 
Operation ( TSO ) atau yang lebih dikenal denganAUTO 2000 adalah jaringan jasa penjualan, perawatan, perbaikan dan penyediaan suku cadang Toyota yang manajemennya ditangani penuh oleh $P T$ Astra Internasional Tbk. Saat ini AUTO 2000 adalah Main Dealer Toyota terbesar yang menguasai antara $70-80 \%$ dari total penjualan Toyota di wilayah Indonesia, salah satunya yang ada di Kota Pelembang yaitu Auto 2000 Tanjung Api-Api Palembang, juga memiliki strategi dan keunggulan yang berbeda dibanding pesaing yang ada, baik dari segi pelayanan, harga, produk, biaya dan emosional yang ditawarkan pun beraneka macam, dengan begitu akan menjadi ciri dan keunggulan tersendiri bagi setiap bengkel. Hal tersebut menuntut pihak pemilik atau pengelola bengkel untuk menciptakan strategi agar mampu bersaing dan unggul dibanding bengkel-bengkel kompetitornya. Adapun data Unit Entry di Bengkel Auto 2000 Tanjung Api-Api Palembang di bulan terakhir dapat dilihat pada tabel berikut ini:

Tabel 1

Data Perbaikan Kendaraan

Periode Juli-Desember 2021

Branch Auto 2000 Palembang Tj. Api-Api

\begin{tabular}{|c|c|c|c|c|c|c|}
\hline BULAN & Januari & Februari & Maret & April & Mei & Juni \\
\hline U.E & 2017 & 2018 & 2102 & 2110 & 2154 & 3012 \\
\hline
\end{tabular}

Sumber: Bengkel Auto 2000 Tanjung Api-Api, 2021

Berdasarkan tabel dan data di atas dapat dilihat dalam enam bulan terakhir selalu ada kenaikan jumlah pelanggan jasa bengkel Auto 2000 Tanjung Api-Api Palembang. Untuk itu perlu dilakukan penelitian dengan judul "Pengaruh Kepercayaan dan Komitmen TerhadapLoyalitas Konsumen Pengguna Jasa Bengkel Auto 2000 Tanjung Api-api Palembang".

\section{2. Perumusan Masalah}

1. Apakah kepercayaan dan komitmen berpengaruh secara parsial dan Simultan terhadap loyalitas konsumen pengguna jasa bengkel Auto2000 Tanjung Api-api Palembang?

2. Apakah ada pengaruh yang dominan diantara variabel kepercayaan dan komitmen secara parsial dan Simultan terhadap loyalitas konsumen pengguna jasa bengkel Auto2000 Tanjung Apiapi Palembang?

\section{3. Tujuan Penelitian}

1. Untuk mengetahui secara parsial dan simultan pengaruh kepercayaan dan komitmen terhadap loyalitas konsumen pengguna jasa bengkel Auto2000 Tanjung Api-api Palembang.

2. Untuk mengetahui pengaruh yang dominan diantara varriabel kepercayaan dan komitmen terhadap loyalitas konsumen pengguna jasa bengkel Auto2000 Tanjung Api-api Palembang.

\section{TINJAUAN PUSTAKA}

\subsection{Landasan Teori}

\subsubsection{Kepercayaan}

Menurut Mowen dan Minor dalam Donni Juni (2017,p.116) Kepercayaan adalah semua pengetahuan yang dimiliki oleh konsumen dan semua kesimpulan yang dibuat oleh konsumen tentang objek, atribut 
dan manfaatnya. Menurut Rousseau et al dalam Donni Juni (2017,p.116) Kepercayaan adalah wilayah psikologis yang merupakan perhatian untuk menerima apa adanya berdasarkan harapan terhadap perilaku yang baik dari orang lain.Menurut Idrees., et al. (2015:35), Kepercayaan merupakan keinginan seseorang dalam menghadapi resiko yang bergatung pada pihak lain. Kepercayaan merek menjadi pedoman konsumen dalam pengambilan keputusan pembelian. oleh karena itu, kepercayaan terhadap merek dapat mengurangi segala resiko dan ketidakpastian, dengan begitu adanaya kepercayaan terhadap merek konsumen akan merasa apa yang dipilihnya itu adalah merek yang terbaik dan memenuhi harapan (Tanojohardjo., et al. 2014:2). Menurut Sumarwan (2011:165), kepercayaan konsumen adalah pengetahuan konsumen mengenai suatu obyek, atributnya, dan manfaatnya. Berdasarkan konsep tersebut, maka pengetahuan konsumen sangat terkait dengan pembahasan sikap karena pengetahuan konsumen adalah kepercayaan konsumen. Kepercayaan konsumen atau pengetahuan konsumen menyangkut kepercayaan bahwa suatu produk memiliki berbagai atribut, dan manfaat dari berbagai atribut tersebut.

\subsubsection{Komitmen}

Peelen dan Beltman (2013:12) mengidentififi kasi tujuan dari commitment yaitu untuk melanjutkan hubungan antara perusahaan dan pelanggan dan memberikan hasil yang saling menguntungkan. Dimensi yang digunakan untuk menilai commitment atau komitmen adalah sebuah keinginan yang besar untuk menjaga hubungan yang berharga. Menurut Moorman, et.al.,(1993) dalam Razak (2017:60), komitmen adalah hubungan antara sikap terhadap bukti fisik, proses, dan karyawan dengan kualitas keterhubungan, serta perannya dalam menimbulkan niat ulang membeli dan loyalitas. Komitmen menyebutkan sebagai hasrat (desire) untuk mempertahankan keterhubungan dalam jangka panjang(enduring desire). Dalam hal ini ditekankan bahwa komitmen adalah unsur perilaku sebagai upaya untuk mempertahankan dan menjaga hubungan jangka panjang antara kedua belah pihak agar hubungan ini lebih bermakna.

\subsubsection{Loyalitas}

Kotler dan Keller (2019:138) mengungkapkan loyalitas adalah "komitmen yang dipegang secara mendalam untuk membeli atau mendukung kembali produk atau jasa yang disukai di masa depan meski pengaruh situasi dan usaha pemasaran berpotensi menyebabkan pelanggan beralih". Loyalitas menurut Tjiptono

(2019:481) "Perilaku pembelian ulang semata mata menyangkut pembelian merek tertentu yang sama secara berulang kali (bisa dikarenakan memang hanya satu satu nya merk yang tersedia, merk termurah dan sebagainya). Menurut Hasan (2015:83) bahwa loyalitas pelanggan adalah pelanggan yang hanya tidak membeli ulang suatu barang dan jasa misalnya dengan merekomendasikan orang lain untuk membeli. Loyalitas menurut Griffin (2010:04), adalah seorang konsumen dikatkan setia atau loyal apabila konsumen menunjukan perilaku pembelian secara teratur atau terdapat suatu kondisi dimana mewajibkan konsumen membeli paling Sedikit dua kali dalam selang waktu tertentu. Menurut Supriyatmini (2005

41) Loyalitas merupakan kesetiaan customer terhadap penyedia jasa yang telah memberikan pelayanan kepadanya. Hurriyati (2005) dalam Sangadji dan Sopiah (2013:104), loyalitas adalah komitmen pelanggan bertahan secara mendalam untuk berlangganan kembali atau melakukan pembelian ulang produk atau jasa terpilih secara konsisten di masa yang akan datang, 
meskipun pengaruh situasi dan usaha-usaha pemasaran mempunyai potensi untuk menyebarkan perubahan perilaku.

\subsubsection{Hubungan Komitmen dan Kepercayaan Terhadap Loyalitas Pelanggan}

Menurut Morgan dan Hunt (1994) dalam Razak (2017:40), dua konsep yang merupakan kunci keberhasilan hubungan yaitu kepercayaan (trust) dan komitmen (commitment). Apabila kepercayaan dan komitmen sudah tercipta di antara pelakupelaku dalam pertukaran, maka hasil yang diperoleh akan lebih efisien, efektif, dan produktif.

\subsection{Penelitian Terdahulu}

1. Penelitian Syifa Amalia, Jalaluddin (2020) dengan judul "Pengaruh Kepercayaan dan Komitmen Terhadap Loyalitas Nasabah Tabungan di PT Bank BNI Syariah Kantor Kas Cinunuk". Hasil penelitian mengungkapkan kepercayaan dan komitmen berpengaruh positip dan signifikan terhadap Loyalitas Nasabah dengan koofisien sebesar 0,017 dan 0,881 dan dari uji koofisien determinasi variabel kepecayaan dan kimitmen terhadap loyalitas diperoleh nilai 60,7 $\%$.
2. Penelitian Pingki Amalia Qulba (2019) dengan judul "Pengaruh Komitmen dan Kepercayaan Terhadap Loyalitas Pelanggan (Studi Pada Pelanggan Guest House Front One Inn De Laia Malang)". Hasil penelitian secara parsial komitmen berpengaruh positif dan signifikan terhadap loyalitas pelanggan Guest House Front One Inn De Laia Malang. Secara parsial kepercayaan berpengaruh positif dan signifikan terhadap loyalitas pelanggan Guest House Front One Inn De Laia Malang. Secara simultan komitmen dan kepercayaan berpengaruh positif dan signifikan terhadap loyalitas pelanggan GuestHouse Front One Inn De Laia Malang.

3. Penelitian Riven Agustien Tahun, Markus Bunga, Antonio E L Nyoko (2018) dengan judul "Pengaruh Kepercayaan dan Komitmen Terhadap Loyalitas Nasabah Pada Bank Perkreditan Rakyat Tanaoba Lais Manekat Kota Kupang". Hasil penelitian kepercayaan dan komitmen berpengaruh positip dan signifikan terhadap Loyalitas Nasabah dengan koofisien sebesar 0,383 dan 0,346 dan dari uji koofisien determinasi variabel kepecayaan dan kimitmen terhadap loyalitas diperoleh nilai $15,1 \%$.

\subsection{Kerangka Pemikiran}

\section{Gambar 1}

Kerangka Fikir

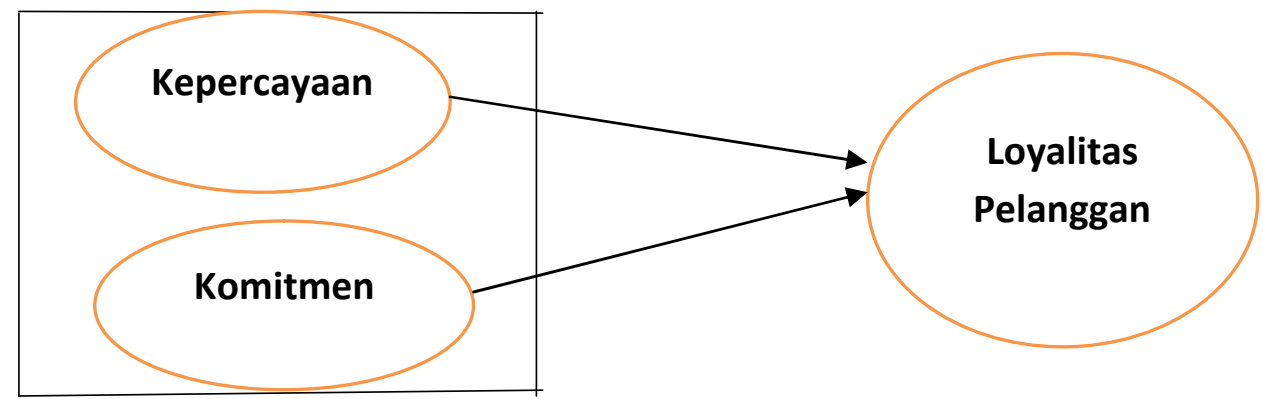




\subsection{Hipotesis}

Berdasarkan rumusan masalah dan kajian teoritis yang dikembangkan maka penulis mengajukan Hipotesis sebagai berikut:

1. Ho : Tidak terdapat pengaruh yang signifikan secara parsial dan simultan antara variabel kepercayaan dan komitmen terhadap loyalitas konsumen pengguna jasa Bengkel Auto2000 Tanjung Api-api Palembang.

Ha: Terdapat pengaruh yang signifikan secara parsial dan simultan antara variabel kepercayaan dan komitmen terhadap loyalitas konsumen pengguna jasa Bengkel Auto 2000 Tanjung Apiapi Palembang.

2. Ho: Tidak terdapat pengaruh yang dominan antara variabel kepercayaan dan komitmen terhadap loyalitas konsumen pengguna jasa Bengkel Auto 2000 Tanjung Api-api Palembang. Ha: Terdapat pengaruh

yang dominan antara variabel kepercayaan dan komitmen terhadap loyalitas konsumen pengguna jasa Bengkel Auto 2000 Tanjung Api-api Palembang.

\section{METODE PENELITIAN}

\subsection{Objek Penelitian}

Objek penelitian ini adalah Konsumen yang menggunakan jasa bengkel Auto 2000 Tanjung Api-api Palembang.

\subsection{Ruang Lingkup Penelitian}

Dalam melakukan penelitian agar tidak menyimpang dari permasalahan yang ada maka penulis menitik beratkan pembahasan pada pengaruh kepercayaan dan komitmen terhadap loyalitas konsumen pengguna jasa bengkel Auto 2000 Tanjung Api-api Palembang.

\subsection{Desain Penelitian}

Metode yang digunakan dalam penelitianini adalah metode eksploratif, menurut Sekaran (2017:155): "Studi eksploratif (exploratory study) dilakukan jika tidak banyak yang diketahui mengenai situasi yang dihadapi, atau tidak ada informasi yang tersedia mengenai bagaimana masalah atau isu penelitian yang mirip diselesaikan di masa lalu.Menurut Sekaran (2017:66): "Mewawancara, memberikan kuesioner, dan mengobservasi orang dan fenomena adalah tigametode pengumpulan data yang utama dalam penelitian survei."

\subsection{Jenis dan Sumber Data}

\subsubsection{Jenis Data}

Menurut Mudrajad Kuncoro (2014:

145) data adalah "sekumpulan informasi yang diperlukan untuk pengambilan keputusan". Terdapat dua jenis data yang digunakan dalam penelitian (Umar, 2014:12) yaitu:

1. Data Kualitatif

Data dalam penelitian biasanya berbentuk kata-kata, gambar dan sedikit angka yang dianalisis dalam terminologi respon-respon individual, kesimpulan deskriptif, atau keduanya. Biasanya data dalam bentuk skala nominal, ordinal, atau interval.

2. Data Kuantitatif

Data kuantitatif mendasarkan hasil penelitian pada perhitungan-perhitungan matematis yang kemudian memberikan gambaran atas suatu fenomena kasus yang diajukan dalam penelitian. Data angka yang dihasilkan menjadi acuan atau parameter tingkat atau level yang telah ditentukan sebelumnya. Cara-cara yang digunakan bisa berupa tes (pra maupun pasca) yang kemudian melalui berbagai proses uji validitas data. 


\subsubsection{Sumber Data}

Ada dua jenis sumber data (Arikunto, 2016: 172) dalam penelitian ini, yaitu:

\section{Data Primer}

Yaitu data yang diperoleh langsung dari responden itu sendiri yaitu konsumen yang membeli mobil pada dealer mobil merek Nissan di Kota Palembang.

2. Data Sekunder

Yaitu data yang terlebih dahulu diperoleh dan dikumpulkan oleh orang lain ataupun dapat juga data yang diperoleh dari internet dan artikel yang berhubungan dengan objek penelitian ( Umar, 2014: 41 ).

\section{5. Populasi dan Sampel Penelitian}

\subsubsection{Populasi}

Populasi adalah gabungan dari seluruh elemen yang berbentuk peristiwa, hal atau orang yang memiliki karakteristik yang serupa yang menjadi pusat perhatianseorang peneliti karena itu dipandang sebagai sebuah semesta penelitian (Ferdinand, 2014:60 ). Adapun Populasi dalam penelitian ini adalah seluruh konsumen yang pengguna jasa bengkel Auto2000 Tanjung Api-api Palembang yang telah melakukan service lebih dari dua kali dalam kurun waktu tiga (3) bulan terakhir, yaitu dari bulan April sampai Juni 2021 yang jumlahnya 3550 orang. Tetapi dari 3550 orang yang mengisi kuesioner dan sudah mengembalikan adalah berjumlah 350 orang.

\subsubsection{Sampel}

Sampel adalah subset dari populasi, terdiri dari beberapa anggota populasi.Teknik pengambilan sampel yang digunakan dalam penelitian ini adalahdengan purposive sampling, yaitu penulis menggunakan pertimbangan sendiri dengan cara sengaja dalam memilih anggota populasi yang dianggap dapat memberikan informasi yang diperlukan oleh penulis
Jumlah sampel dalam penelitian ditentukan berdasarkan rumus Slovin dikutip oleh Husein Umar (2014:108) adalah sebagai berikut:

$$
\mathrm{n}=\frac{\mathrm{N}}{1+\mathrm{Ne}^{2}}
$$

Di mana :

$$
\begin{array}{ll}
\mathrm{n}: & \text { Ukuran Sampel } \\
\mathrm{N}: & \begin{array}{l}
\text { Ukuran Populasi yaitu jumlah } \\
\text { total pelanggan PT Bentara }
\end{array} \\
\mathrm{e}: & \begin{array}{l}
\text { Sinergies Multifinance } \\
\text { Nilai kritis }
\end{array} \\
\mathrm{n}= & \frac{\mathrm{N}}{1+\mathrm{Ne}^{2}} \\
=\frac{350}{1+350\left(0,10^{2}\right)} \\
=77,77
\end{array}
$$

Dibulatkan menjadi 78

\subsection{Teknik Analisis Data}

Penelitian ini menggunakan analisis Regresi Berganda dengan pengolahan data menggunakan SPSS 20 for Windows. Adapun tahapan-tahapan Analisis adalah sebagai berikut:

\section{Uji Validitas dan Reliabilitas}

1.1. Uji Validitas

Uji validitas digunakan untuk mengukur sah atau valid tidaknya suatu kuesioner. Suatu kuesioner dikatakan valid jika pertanyaan dan kuesioner mampu untuk mengungkap sesuatu yang akan diukur oleh kuesioner tersebut (Ghozali, 2016: 45).

\subsection{Uji Reliabilitas}

Reliabilitas adalah alat untuk mengukur suatu kuesioner yang merupakan indikator dari suatu variabel. Suatu kuesioner dikatakan reliabel atau handal jika jawaban pertanyaan adalah konsisten atau 
stabil dari waktu ke waktu (Ghozali, 2016: 41). Suatu variabel dikatakan reliabel jika nilai Cronbach Alpha (a) > 0,6.

\section{Uji Asumsi Klasik}

Uji asumsi klasik yang digunakan dalam penelitian ini adalah:

1. Uji Normalitas

Uji Normalitas pada model regresi digunakan untuk menguji apakah nilai residual yang dihasilkan dari regresi terdistribusi secara normal atau tidak. Jika signifikan $>0,05$ maka variabel berdistribusi normal dan sebaliknya, jika signifikan $<0,05$ maka variabel tidak berdistribusi normal Ghozali dalam Sujarweni (2015:225).

\section{Uji Multikolinieritas}

Uji ini bertujuan untuk menguji suatu model apakah dalam mode sebuah regresi ditemukan adanya korelasi antar variabel independen. Ada yang multikolinieritas dapat dilihat dari toleran cevalue atau nilai Value Inflation Factor (VIF) melalui program Statistical Package forThe Social Sciencefor windows. Batas tolerancevalue adalah 0,1 dan batas VIF adalah 5, dimana:

1. Tolerance Value $<0,1$ atau VIF $>5$ maka terjadi multikolinieritas.

2. Tolerance Valie $>0$, latau VIF $>5$ maka tidak terjadi multikolinieritas

\section{Uji Heteroskedastisitas}

Uji ini dilakukan untuk menguji apakah dalam sebuah model regresi terjadi ketidak samaan varians dari residual suatu pengamatan kepengamatan lain. Jika varians dari residual atau dari suatu pengamatan kepengamatan yang lain tetap, maka disebut homoskedastisitas, dan jika varians berbedamaka disebut heteroskedastisitas.

\section{Analisis Regresi Linier Berganda}

Persamaan regresi dalam penelitian ini adalah:

$$
\mathbf{Y}=\mathbf{a}+\mathbf{b}_{1} \mathbf{X}_{1}+\mathbf{b}_{2} \mathbf{X}_{2}+\mathbf{e}
$$

\section{Pengujian Hipotesis}

1. Uji Parsial (Uji t)

Uji $t$ digunakan untuk menguji signifikansi hubungan antara variabel $\mathrm{X}$ dan $\mathrm{Y}$, apakah variabel X1, X2, benar-benar berpengaruh terhadap variabel $\mathrm{Y}$ secara terpisah atau parsial (Ghozali, $2016: 88$ ).

\section{Uji F}

Dalam penelitian ini, uji $\mathrm{F}$ digunakan untuk mengetahui tingkat siginifikansi pengaruh variabel-variabel independen secara bersama-sama (simultan) terhadap variabel dependen (Ghozali 2016:89)

\section{Koefisien Determinasi $\left(\mathrm{R}^{2}\right)$}

Koefisien determinasi $\left(\mathrm{R}^{2}\right)$ pada intinya mengukur seberapa jauh kemampuan model dalam menerangkan variasi varabel terikat. Nilai koefisiende terminasi adalah antar nol dan satu $\left(0<\mathrm{R}^{2}<1\right)$. Nilai $\mathrm{R}^{2}$ yang kecil berarti kemampuan variabel independen dalam menjelaskan variasi variabel dependen amat terbatas.

\section{HASIL PENELITIAN DAN PEMBAHASAN}

\subsection{Analisis Data}

\subsubsection{Uji Validitas}

Suatu kuesioner dikatakan valid jika pertanyaan dan kuesioner mampu untuk mengungkap sesuatu yang akan diukur oleh kuesioner tersebut (Ghozali, 2016: 45). 
Tabel 2

Hasil Uji Validitas

\begin{tabular}{|c|c|c|c|c|c|}
\hline No & Variabel & $\begin{array}{c}\text { Butir } \\
\text { Pernyataan }\end{array}$ & r hitung & $\mathrm{r}$ tabel & Keterangan \\
\hline \multirow{5}{*}{1} & \multirow{5}{*}{ Kepercayaan } & P1 & 0,454 & 0,234 & Valid \\
\hline & & $\mathrm{P} 2$ & 0,748 & 0,234 & Valid \\
\hline & & P3 & 0,733 & 0,234 & Valid \\
\hline & & $\mathrm{P} 4$ & 0,690 & 0,234 & Valid \\
\hline & & P5 & 0,738 & 0,234 & Valid \\
\hline \multirow{5}{*}{2} & \multirow{5}{*}{ Komitmen } & $\mathrm{P} 1$ & 0,765 & 0,234 & Valid \\
\hline & & $\mathrm{P} 2$ & 0,565 & 0,234 & Valid \\
\hline & & P3 & 0,768 & 0,234 & Valid \\
\hline & & $\mathrm{P} 4$ & 0,698 & 0,234 & Valid \\
\hline & & P5 & 0,565 & 0,234 & Valid \\
\hline \multirow{4}{*}{3} & \multirow{4}{*}{ Loyalitas } & $\mathrm{P} 1$ & 0,694 & 0,234 & Valid \\
\hline & & $\mathrm{P} 2$ & 0,775 & 0,234 & Valid \\
\hline & & P3 & 0,785 & 0,234 & Valid \\
\hline & & $\mathrm{P} 4$ & 0,650 & 0,234 & Valid \\
\hline
\end{tabular}

\subsubsection{Uji Reliabilitas}

Suatu kuesioner dikatakan reliabel atau handal jika jawaban pertanyaan adalah konsisten atau stabil dari waktu ke waktu (Ghozali, 2016: 41). Suatu variabel dikatakan reliabel jika nilai Cronbach Alpha (a) $>0,6$.

Tabel 3

Hasil Uji Relibilitas

\begin{tabular}{|c|c|c|c|c|}
\hline No & Variabel & C.R & Standa & Keterangan \\
\hline 1 & Kepercayaan & 0,747 & 0.600 & Reliabel \\
\hline 2 & Komitmen & 0,721 & 0.600 & Reliabel \\
\hline 3 & Loyalitas & 0,692 & 0.600 & Reliabel \\
\hline
\end{tabular}

\subsubsection{Uji Asumsi Klasik}

1. Uji Normalitas Data

Tujuan dari uji normalitas adalah untuk menentukan apakah variabel berdistribusi nor mal atau tidak. Pengujian normalitas dilakukan dengan menggunakan uji Kolmogorov - Smirnov. Jika tingkat signifikansi probabilitas $>0.05$ maka data penelitian berdistribusi normal. Hasil uji normalitas dengan menggunakan program SPSS adalah sebagai berikut 
Tabel 4

One-Sample Kolmogorov-Smirnov Test

\begin{tabular}{|c|c|c|}
\hline & & $\begin{array}{l}\text { Unstandardized } \\
\text { Residual }\end{array}$ \\
\hline \multicolumn{2}{|l|}{$\mathrm{N}$} & 100 \\
\hline \multirow{2}{*}{\multicolumn{2}{|c|}{$\begin{array}{c}\text { Mean } \\
\text { Normal Parametersa,b }\end{array}$}} & ,0000000 \\
\hline & & \\
\hline \multirow{2}{*}{\multicolumn{2}{|c|}{ Std. Deviation }} & 5,23177797 \\
\hline & & ,089 \\
\hline \multicolumn{3}{|l|}{ Most Extreme Differences } \\
\hline & Positive & 089 \\
\hline & Negative &,- 079 \\
\hline \multicolumn{2}{|l|}{ Kolmogorov-Smirnov Z } & ,959 \\
\hline \multicolumn{2}{|l|}{ Asymp. Sig. (2-tailed) } & ,361 \\
\hline
\end{tabular}

Berdasarkan hasil uji normalitas di atas, terlihat nilai Asymp. Sig. (2-tailed) sebesar 0.361 dengan probabilitas $>0.05$ maka data penelitian berdistribusi normal.disamping menggunakan uji Kolmogorov-Smirnov, uji normalitas ini juga didukung dari hasil gambar normal probability plot.

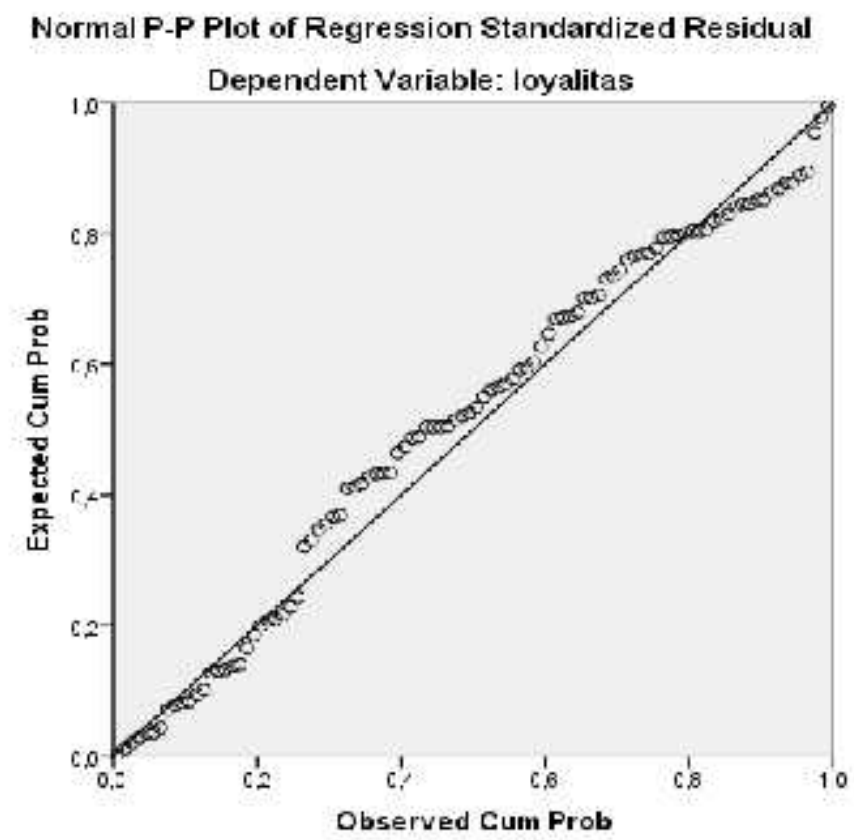

Gambar 2: Normal P-P Plot dengan Variabel Dependen Loyalitas Konsumen 


\section{Uji Heteroskedastisitas}

\section{Metode Grafik}

\section{Gambar 3}

Scaterplot Uji Heteroskedastisitas

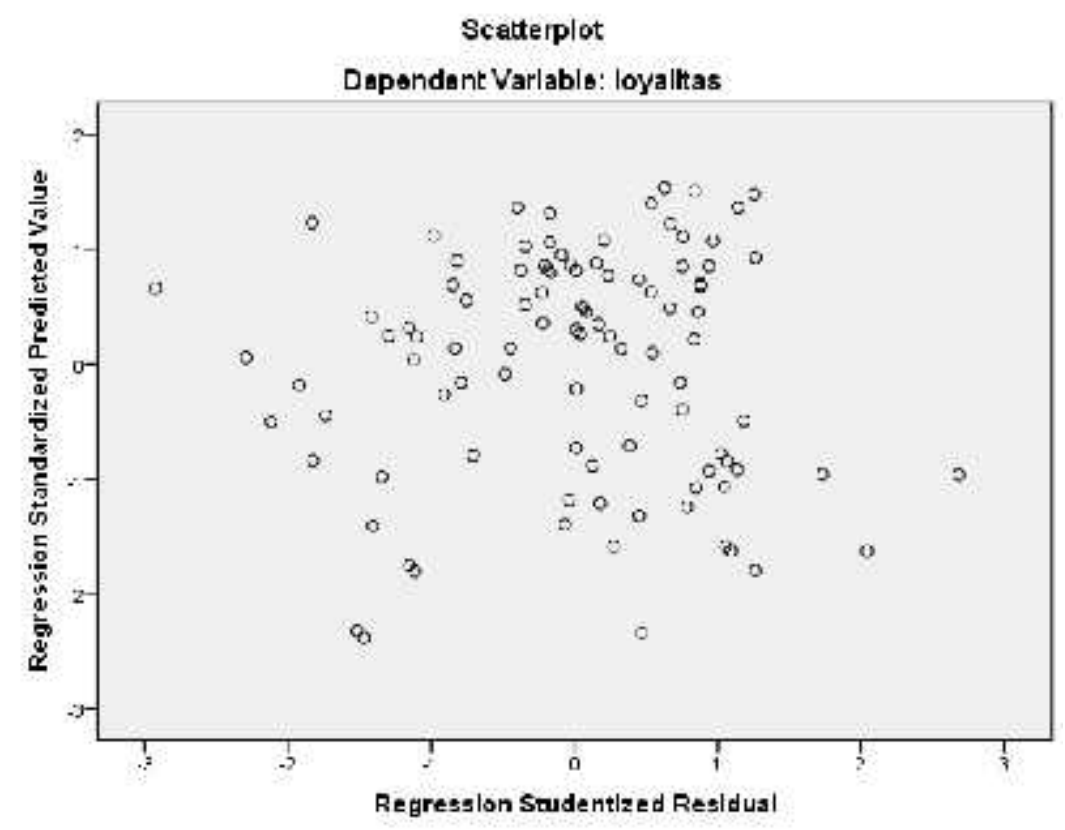

3. Uji Multikolinieritas

Untuk mendeteksi ada tidaknya gejala multikolinearitas maka dilakukan dengan melihat Variance Inflation Factor (VIF), bila nila VIF lebih kecil dari 10 maka tidak terjadi multi kolinieritas.

Tabel 5

Uji Multikolinieritas

\begin{tabular}{|c|c|c|}
\hline Variabel & VIF & Keterangan \\
\hline $\mathrm{X} 1$ & 4,917 & Non Multikolinieritas \\
\hline $\mathrm{X} 2$ & 4,946 & Non Multikolinieritas \\
\hline
\end{tabular}

Berdasarkan Tabel 5 diketahui bahwa diantara variabel-variabel bebas yang digunakan mempunyai nilai VIF lebih kecil dari 10, dari hasilterse but dapat disimpulkan bahwa model regresi linier tersebut bebas dari multikolinearitas atau tidak terjadi korelasi diantara satu dengan yang lain.

\subsubsection{Uji Analisis Regresi Berganda}

Perhitungan regresi linier berganda digunakan untuk memprediksi besarnya hubungan antara variabel terikat (dependen), dengan variabel bebas (independen). 
Tabel 6

Hasil Uji Analisis Regresi Berganda

Coefficients $^{\mathrm{a}}$

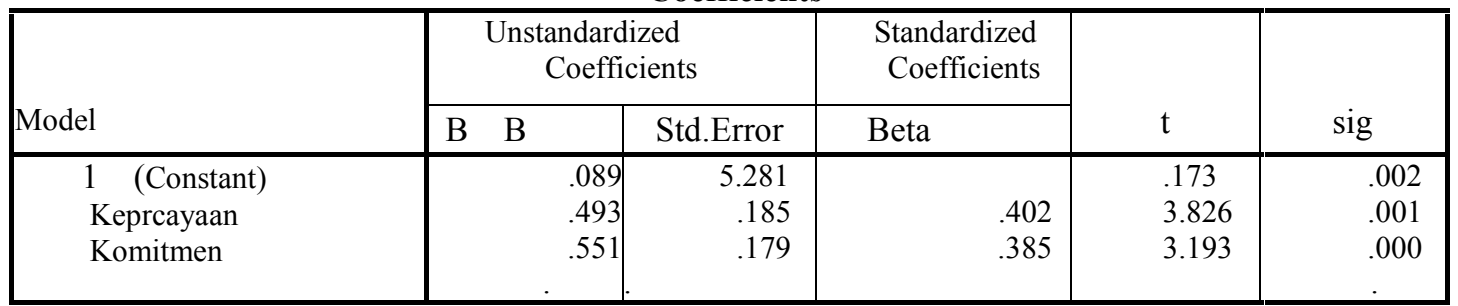

Dependent Variabel: Loyalitas

Model persamaan regresi yang dapat dituliskan dari hasil tersebut dalam bentuk persamaan regresi sebagai berikut :

$$
\mathrm{Y}=0,89+0,493 \mathrm{X} 1+0,551 \mathrm{X} 2+\mathrm{e}
$$

\subsubsection{Uji Hipotesis}

\section{Uji Signifikan Simultan (Uji-f)}

Hasil pengujian hipotesis $\mathrm{F}$ dapat dilihat pada tabel berikut:

Tabel 7

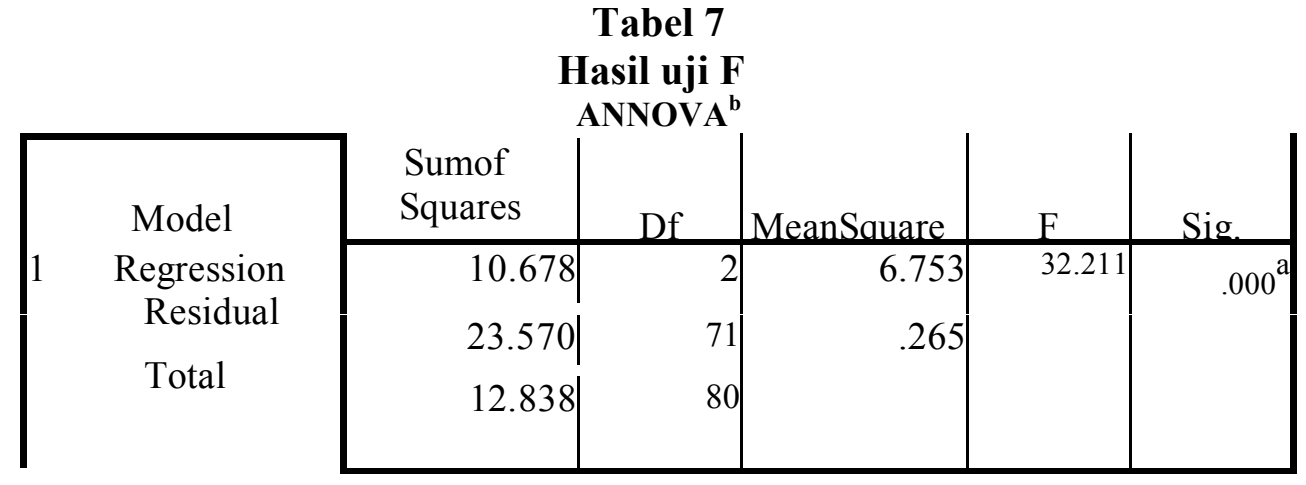

\section{Uji Signifikasi Parsial (Uji-t)}

Dari hasil Uji t dari tabel 6secara rinci dapat dijelaskansebagaiberikut:

- Kepercayaan (X1) terhadap loyaliats (Y) Untuk variabel kepercayaan(X1) memiliki nilai signifikansi 0,001 . Nilai Sigt $<5 \%(0,000<0,05)$. Dengan demikian kepercayaan (X1) berpengaruh signifikan terhadap loyalitas(Y).

- Komitmen (X2) terhadap loyalitas(Y) Untukvariabel komitmen (X2 )memiliki nilai signifikansi 0,000. Nilai Sig $\mathrm{t}<5 \%(0,001<0,05)$. Dengan demikian komitmen $(\mathrm{X} 2)$ berpengaruh signifikan terhadap loyalitas(Y).

\section{Uji Koefisien Korelasi $(R)$ dan Determinasi $\left(R^{2}\right)$}

\section{Tabel 8}

\section{Hasil Uji Determinasi}

Model Summary

\begin{tabular}{|l|r|r|r|r|r|}
\hline Model & $\mathrm{R}$ & $\mathrm{R}$ Square & $\begin{array}{c}\text { Adjusted } \mathrm{R} \\
\text { Square }\end{array}$ & $\begin{array}{c}\text { Std. Error of the } \\
\text { Estimate }\end{array}$ & Durbin-Watson \\
\hline 1 & $.580^{\mathrm{a}}$ & .336 & .323 & 5.528 & 1.603 \\
\hline
\end{tabular}

Berdasarkan tabel8 dapat diketahui bahwa koefisien determinasi $\left(\mathrm{R}^{2}\right)$ sebesar 0,336 atau 33,6\%. 


\section{KESIMPULAN DAN SARAN}

\subsection{Kesimpulan}

Dari rumusan masalah penelitian yang diajukan, maka analisis data yang telah dilakukan dan pembahasan yang telah dikemukakan pada bab sebelumnya, dapat ditarik beberapa kesimpulan dari penelitian ini adalah sebagai berikut :

1. Secara Simultan variabel kepercayaan dan komitmen berpengaruh positif dan signifikan terhadap loyalitas konsumen pengguna jasa bengkel Auto2000 Tanjung Api-api Palembang.

2. Secara parsial kepercayaan dan komitmen berpengaruh positif dan signifikan terhadap loyalitas konsumen pengguna jasa bengkel Auto2000 Tanjung Api-api Palembang dengan nilai koofisien kepercayaan sebesar 0,493 dan nilai koofisien komitmen sebesar 0,551.

3. Berdasarkan uji koofisien determinasi $\left(\mathrm{R}^{2}\right) \quad$ kepercayaan dan komitmen berpengaruh sebesar 0,336 atau 33,6\% dan sisanya 66,4 dipengaruhi oleh variabel lain yang tidak dibahas dalam penelitian ini.

\subsection{Saran}

1. Bagi Auto2000 Tanjung Api-api Palembang harus lebih meningkatkan variabel kepercayaan konsumen agar tetap dapat menjaga komitmen konsumen terhadap Auto2000 Tanjung Api-api Palembang.

2. Diperlukan penelitian lanjutan bagi variabel kepercayaan, komitmen dan loyalitas karena ada banyak hal yang dapat dikaji lagi pada variabel yang diteliti, sehingga akan memberikan masukan bagi pihak-pihak lain yang berkepentingan dan dapat memberikan masukan bagi dunia bisnis.

3. Untuk memperoleh penjelasan yang lebih komperensif tentang pengaruh Kepercayaan dan Komitmen terhadap
Loyalitas, maka dalam penelitian berikutnya disarankan agar dapat mengembangkan dimensi variabel yang lain.

\section{DAFTAR PUSTAKA}

Ali Hasan, (2015), Marketing dan Kasuskasus Pilihan, CAPS Yogyakarta

Arikunto Suharsimi (2016) Prosedur Penelitian Suatu Pendekatan Praktik PT Rineka Cipta Jakarta

Fandy Tjiptono, (2019). Strategi Pemasaran Edisi III, Penerbit Andi, Yogyakarta

Ferdinand, Augusty (2014), Metode Penelitian Manajemen Edisi 2, Badan Penerbit Universitas Diponegoro, Semarang

Ghozali Imam, (2016). Aplikasi Analisis Multivariate Dengan Program SPSS Universitas Diponegoro, Jakarta..

Griffin, Jill.(2010). Customer Loyalty terjemahan Dwi Kartini Yahya. Erlangga Jakarta:

Idrees, Z., Xinping X, Hafi, K., Hua.,\& Nazeer, A (2015) Consumer"s brand trust and its link to brand loyalty American Journal of Business Economic and Management Vol 3 No.2, 34-39

Kotler dan Keller, (2019). Manajemen Pemasaran Edisi Kedua Belas Jilid 2 PT Indeks, Jakarta..

Mudrajat Kuncoro, (2014). Metode Riset Untuk Bisnis \& Ekonomi Bagaimana Meneliti \& Menulis Tesis Edisi 3 Penerbit Airlangga, Jakarta.

Peelen dan Beltman (2013), Customer Relationship Management United Kingdom Person Education.

Pingki A Qulba, Siti Nurbaya (2019), Pengaruh Komitmen dan Kepercayaan Terhadap Loyalitas Pelanggan (Studi pada Pelanggan Guest House Front One Inn De Laia 
Malang), JAB Jurnal Aplikasi Bisnis Volume 5 Nomor 1

Priansyah Doni Juni (2017), Perilaku Konsumen Dalam Persaingan Bisnis Kontemporer, Alfabeta Bandung

Razak, Abdul. 2017. Demografi Nasabah Sebagai Variabel Moderasi Pengaruh Kepuasan, Kepercayaan Dan Komitmen Terhadap Loyalitas Pada Bank Di Sulawesi Tenggara. Yogyakarta: Gawe Buku

Sangadji, M., dan Sopiah (2013), Perilaku Konsumen Pendekatan Praktis, Andi Offset Yogyakarta

Sekaran, Uma dan Bougie R (2017) Metode Penelitian untuk Bisnis Pendekatan Pengembangan keahlian, Salemba empat Jakarta

Sumarwan Ujang, (2011), Perilaku Konsumen Ghalia Indonesia Bogor

Sujarweni, Wiratna (2015), SPSS untuk Penelitian, Pustaka Baru Press Jakarta

Supriyatmini Tuti, Pengaruh Kualitas Pelayanan Terhadap Loyalitas Nasabah Pada Baitul Mal Wattanwil (BMT) Kafah Semarang, UNNES, 2005

Syifa A, Jalalludin, (2020), Pengaruh Kepercayaan dan Komitmen terhadap Loyalitas Nasabah Tabungan di PT Bank BNI Syariah Kantor Kas Cinunuk, Journal of Islamic Economics and Business Fakultas Ekonomi dan Bisnis Islam UIN Sunan Gunung Djati Bandung

Tahun, Bunga and Nyoko (2018), Pengaruh Kepercayaan dan Komitmen terhadap Loyalitas Nasabah pada Bank Perkreditan Rakyat Tanaoba Lais Manekat Kota Kupang, Journal of Manajemen $\quad$ (SME's) Volume 7 Nomor 2

Tanojohardjo, G.A., Kunto, Y. S., \& Brahmana, R. K. M. R. (2014). Analisa Hedonic Value dan Utilitaria Valua Terhadap Brand Trust dengan
Brand satisfaction Sebagai Variabel Intervening Pada Produk Perawatan L"OREALPROFESSIONNEL. Jurnal Manajemen Pemasaran Petra Vol 2 No 1, 1-11.

Umar, H (2014). Metode Penelitian untuk Skripsi dan Tesis Bisnis. PT. Raja Grafindo Perkasa, Jakarta 